\title{
Implications of transforming climate change risks into security risks
}

\author{
Ksenia Chmutina ${ }^{a}$, Peter Fussey ${ }^{b}$, Andrew Dainty ${ }^{c}$, Lee Bosher ${ }^{d}$ \\ a Corresponding author: School of Civil and Building Engineering, Loughborough University, \\ Loughborough, LE11 3 TU, UK. Email: k.chmutina@lboro.ac.uk. Tel: +44(0)1509228526 \\ ${ }^{\mathrm{b}}$ Department of Sociology, University of Essex, UK. Email: pfussey@essex.ac.uk \\ c School of Civil and Building Engineering, Loughborough University, UK. Email: \\ A.R.J.Dainty@lboro.ac.uk \\ ${ }^{\mathrm{d}}$ School of Civil and Building Engineering, Loughborough University, UK. Email: \\ l.bosher@lboro.ac.uk
}

\section{Introduction}

Recently climate change has moved to the top of political agendas in many countries, with the prevailing political discourse advocating adaptation and mitigation of present and anticipated effects of climate change as they affect development of the nations (Mercer, 2010). Labelled as perhaps the greatest global crisis humanity has ever faced and referred to as 'climate breakdown' (Monbiot, 2013), climate change is seen as a global long-term disaster (King, 2004), and a threat to both social and political stabilities (Abbott et al., 2007; Fussey and South, 2012).

Climate change adaptation (CCA) in particular has been discussed as an integral part of disaster risk reduction (DRR) (Kelman et al., 2017) - and thus resilience, however security frames are becoming increasingly prominent for understanding, mitigating and adapting to its impacts. Major shifts in the political landscape during 2016 (e.g. Brexit, the US elections) have brought further and unexpected transformation to such imbrications of security and climate change. In particular, the rise of the 'alt-right', 'post-truth' politics have heightened the emphasis on protectionist and security-based responses to complex global problems. This has been most pronounced in Trump's America, where security has become configured in a more parochial sense: a protectionist reflex that emphasises the integrity of national borders and restrictions on flows of labour, economy and variously imagined foreign menaces, and acquired a prominence not seen for decades. Simultaneously, and relatedly, the influence and very existence of seemingly abstract threats such climate change become relegated and denied (e.g. Hollander, 2017). As these processes continue to advance, understanding the role of security, and its evolving relationship with climate change, becomes more pressing and urgent.

Drawing upon the UK context, this paper argues that the issue of climate change has become framed increasingly in terms of security, and seeks to identify a range of drivers that have shaped and modulated this process. In doing so, we identify both the existence of this series of broader securitising tendencies and their situation against a number of prominent understandings of this relationship. Some argue that securitisation of climate change will lead towards its militarisation and the use of traditional security instruments that invite security-focused responses at the expense of tackling the roots of climate change (von Lucke et al., 2014), while others believe that it is impossible to securitise climate change since it is framed through future scenarios and involves too many unknowns (Rasmussen, 2006). As a corollary, questions become raised over the way climate related perturbations that are amenable to actionable responses, phenomena that can be understood and resolved within existing frames of policy and practice, become prioritised. There are also 
arguments that the focus should be on mitigation and governance of climate change instead of solely treating it as a direct threat (Corry, 2012).

The discussion around the securitisation of climate change is not new (e.g. Barnett, 2003; McDonald, 2013) but it has largely focused on the analysis of international policy. In the UK, securitisation of climate change has been discussed in the context of migration (Boas, 2015), energy (Shin and Choi, 2015), and nature (Davoudi, 2014). This paper employs critical discourse analysis in order to understand the shifts in the role of climate change in the national policy and to explore its securitisation in the context of climate change risks at a national level.

\section{The process of securitisation}

Securitisation is defined as a successful speech act, 'through which an intersubjective understanding is constructed within a political community to treat something as an existential threat to a valued referent object, and to enable a call for urgent and exceptional measures to deal with the threat' (Buzan and Waever, 2003, p. 491), a perspective that informs our approach. While often reduced to ideas around a growing dominance of security discourse, careful attention to the conceptual origins of securitisation theory adds particularly valuable elements to our understanding of shifting approaches to climate change. As a starting point (Buzan, 1991; Buzan et al., 1998), securitisation is principally concerned with the way a range of politicised processes configure subjects as problems of security (or as something in need of securitising).

The key - and often underplayed - element of this theory is the role of intersubjectivity, a concept that promotes a series of other issues to analytical prominence, including those concerning security governance and security discourse. Intersubjectivity constitutes an important site of analysis given that it accommodates points of fractional coherence in the ways threats are framed by different actors. This attends to neither 'objective' consensual understandings of threats, nor subjective perspectives on them, but a more relational yet accepted perspective of threats. Thus, whilst there may be a shared understanding that a threat exists, the meanings attributed to it may vary (hence 'intersubjectivity'). As theorised in this sense, securitisation theory comprises a further, communicative, element: 'a sustained strategic practice aimed at convincing a target audience to accept, based on what it knows about the world, the claim that a specific development (oral threat or event) is threatening enough to deserve an immediate policy to alleviate it' (Balzacq, 2005, p.173, emphasis in original).

A key theme of these original formulations of securitisation theory, then, is the emphasis given to different institutional domains, subject to varying vulnerabilities, threats, survival strategies and organisational responses. Crucially, proponents of securitisation theory seek to identify how such processes are seen to identify threats to an increasing range of objects and domains in need of securitising.

Numerous criticisms of securitisation theory have gained prominence in recent years. Many of these relate to the way securitisation activities are reduced to fixed and immutable mechanisms (Balzacq, 2005), or a supposed linearity where securitisation processes are seen be part of ambitions for total security (Fussey and Coaffee, 2012). Perhaps most prescient are criticisms that interrogate crucial differences between threats and risks and their relationship to such theoretical formulations. Here, the precipitous 
growth of 'risk' in all its manifestations - as a technique for 'taming' the future, technology of governance and as a behemoth for critical analyses - creates particular problems for the explanatory potential of securitisation theory. Threats pose a challenge to existential endurance and therefore focus responses to modes of survival (Huysmans, 1998). Risks do not. This observation has led numerous critics to question the continued relevance of securitisation theory given the far greater attention afforded to issues of risk, rather than threat, over the last 20 years.

Owing to the nature of emerging threats, security is increasingly thought of in terms of a risk of a threat (rather than a threat itself): a threat is an identified danger that can be stopped, whereas risk is a future possibility, and therefore a policy is needed to control or mitigate it. Risks that do not materialise still remain potential risks (Corry, 2012). Consequently, this shift towards the logic of risk elevates the emphasis on vulnerability, and raises important questions over attendant policy practices.

Provision of security is traditionally seen as the core responsibility of a nation-state that manages external and internal threats to national security within a geographically defined territory. However, such definition has recently been challenged by the inclusion of nonmilitary threats that have a non-state nature (international terrorism, pandemics) into the security agendas of nation-states (Fjader, 2014). The UK's National Security Strategy (NSS) states that the risks of global threats are more prominent as 'we are one of the most open societies, in a world that is more networked than ever before' (HMG, 2010, p. 3) and refers to a myriad of new threats, including climate change. Many of these emerging risks are anthropogenic in nature, so modern society 'has increasingly become a risk society in a sense that it is increasingly occupied with debating, preventing and managing risks that it itself has produced' (Beck, 2008, p.1).

\section{Securitisation of climate change risks}

Security policy is often seen as synonymous with the thematics of national security (McDonald, 2013). However, in the context of climate change, the concept of human and livelihood security attains additional relevance: security responses to climate change risks include adaptation to natural hazards and increasing resilience (Schafer et al., 2016). Climate change has become part of an international security discussion since the mid2000s; it was first mentioned in 2007 in the first Security Council debate on climate change security, followed in 2009 by the first General Assembly debate on climate change security, and a second debate in 2011, followed by informal remarks in 2013 (Boas, 2015; Scott, 2012). Boas and Rothe (2016) argue that the relationship of climate change and security should be analysed through the lens of environmental and human security, risks and threats as well as national and international conflicts, and that climate security should be discussed in terms of complexity, preparedness, decentralisation and empowerment. Climate change is now seen as a security risk because it can impede development of a nation (Floyd, 2008). It is also important to remember that 'the threat to our climate security comes not from outside but from within: we are all our own enemies' (Beckett, 2007, p. 56).

The risk of climate change is largely future-oriented as the impacts are uncertain. However, the evidence of the increase in frequency and intensity of climate change impacts is becoming more apparent when looking at the recent climate-related natural hazards (IPCC, 2014). Climate change does not fit neatly into the traditional security discourse as it lacks 'friend-enemy' logic (Boas and Rothe, 2016). Instead, climate risks are seen as a part of resilience agenda, which is in turn a part of a security agenda (Coaffee and Fussey, 2015; 
Chmutina et al., 2016). The word 'security' makes a risk more noticeable in the eyes of government, thus ensuring that the risk is suitably prominent in government agendas (de Wilde, 2008). This specific prominence and rendering of risk to government bodies thus allows them to become actionable and governable through the tools, assets and frames available to these same institutions. Risks are authored in the image of their discoverers.

This trend is clear in the UK: whilst the original intention of the UK climate change policy framework was focused on mitigation, it has gradually expanded towards adaptation; with CCA eventually becoming a prominent part of security policy frameworks (Figure 1). Such shift has largely been triggered by a number of severe weather events (floods in 1998 and 2007; 2013 Heatwave; 2014 and 2015 Winter storms), encouraging not only some improvements in emergency management, but also in preparedness (i.e. CCA). The UK NSS states: 'The physical effects of climate change are likely to become increasingly significant as a 'risk multiplier', exacerbating existing tensions around the world' (HMG, 2010, p.17). The National Risk Register (NRR) describes climate change as 'not only a future challenge', as the results of it are already apparent in the UK (Cabinet Office, 2017, p.8). Despite the high level of political attention to this issue, there have been considerable variants to how CCA has been translated into practice. Seeing climate change as a 'risk multiplier' means that existing ways of dealing with things are deemed sufficient. Rather than undertaking difficult and expensive transformative action, all that is required is an intensification of current approaches.

\section{IPCC identifies the risk of climate change as inevitable: increase in frequency and intensity of climate-induced natural hazards}

Step 1: Identification of an existential threat to a 'valued referent object'
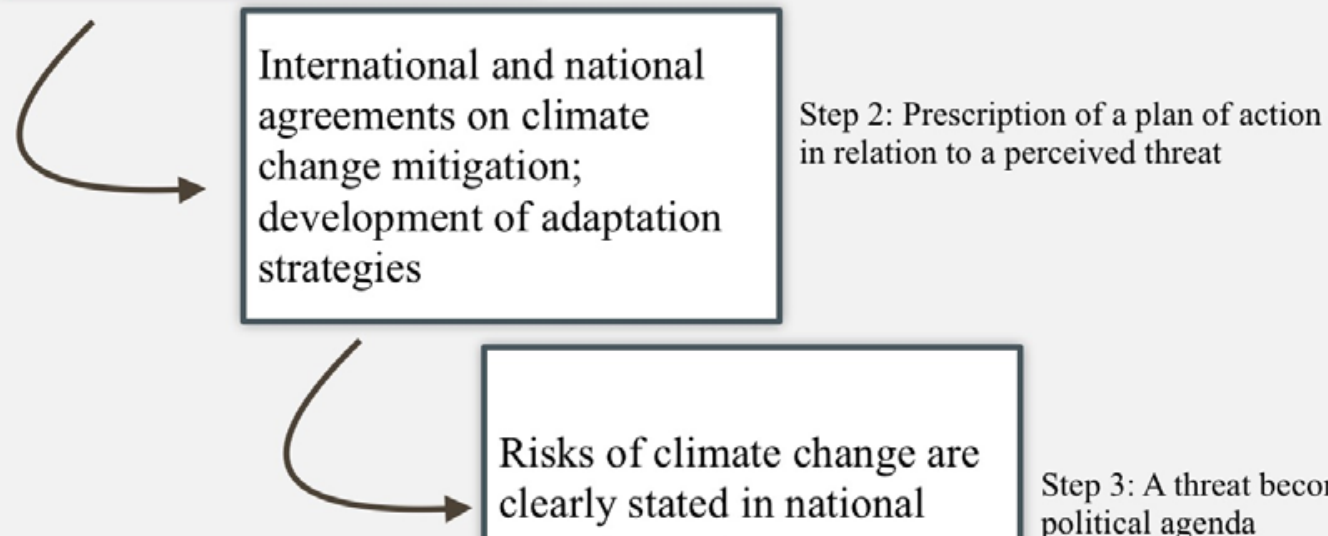

Risks of climate change are clearly stated in national security-related documents

Step 3: A threat becomes a part of a political agenda

Figure 1 Securitisation of climate change in the UK (adapted from Corry, 2012)

The UK is often seen as the first country to discuss climate change as a security issue in policy, and was one of the first countries to introduce a Climate and Energy Security Envoy (in 2009) and departments dedicated to climate change-related security issues (Boas and Rother, 2016). The UK has played an important role in promoting the securitisation of climate change internationally, particularly during its 2007 Presidency of the UN's Security 
Council, when the UK called the first ever meeting on the impacts of climate change.

Expressing a now-common refrain, the chair of the session Margaret Beckett MP stated that climate change had become a collective security issue as we now live in an inter-dependent world (Brito, 2009) and listed border disputes, migration, energy supplies and other resource shortages, societal stresses and humanitarian crises as the issues closely associated with climate change (UK Missions to the UN, 2007). Embracing a new understanding of national security, the UK government has adopted a risk-based 'all hazards' and 'all of society' approach (Fjader, 2014). Securitisation of climate change was also driven by security of water, food and energy supply, which are seen as catalysis of human and national security as availability of these resource affects states and citizens (Schefer et al., 2016).

Such developments raise important questions over the reach, scope and focus of securitisation processes as they apply to climate change. Moreover, how these processes are driven, mediated and modulated reveal how selective articulations of risk (and preferred mechanisms for its amelioration) attain prominence.

\section{Methodology}

This paper extends the application of a constructivist approach by exploring how various events and discourses shape the securitisation of climate change risks. The analysis is empirically informed by companioning discourse analysis (Hajer, 1995) with focus group methodologies to explore how discursive realities are constructed within the discourse of climate change, risks and security. Sources of data included key UK policy documents and parliamentary debates, and a large multi-staged focus group.

More specifically, we develop an approach drawing on Critical Discourse Analysis methods (as proposed by Fairclough 1992 and is used by, for instance, Rogers-Hayden et al., 2011, p.135); it emphasises the political processes that create meaning by enabling 'the examination of language as integral in the creation of discursive reality'. Such an approach allows identifying how a certain discourse becomes hegemonic by making its beliefs 'normalised'. This method was applied through the analysis of three elements: text, discursive practices, and social practices (Figure 2). 
Social Practice: What are the political, social, environmental and economic processes that led to the securitisation of climate change risks?

(Literature and policy analysis)

Discursive Practice: Where was the securitisation of climate change risks evidence? (Policy analysis and focus group)

Text: What are the influencers/ effects of securitisation of climate change risks? (Focus group and policy analysis)

Figure 2 Research framework (based on Fairclough, 1992)

The first element - Social practice - in the larger social, political and historical context within which the Discursive practice operates. Such a framework allows exploring the discourse in which the meanings embedded in the text come to exist within wider social context. The second element - Discursive practice - helps establish the context within which the Text exists and to understand where the evidence for the securitisation of climate change risks can be found. The third element - Text - demonstrates how the securitisation of climate change is discussed in the written and oral form (Fairclough, 1992). All steps have been interrogated through the analysis of existing academic literature, 70 policy and parliamentary documents (Appendix 1), and notes captured during an eight-hour multi-stage focus group organised by the authors.

Focus group methodology (inter alia Bryman 2012) was drawn upon to access both individual and organisational understandings, framing and operationalisation of climate change through narratives of security. 23 distinguished security experts and senior policymakers (Appendix 2) took part in a focus group in January 2015. Its aim was not to discuss climate change as a security issue; instead, this theme was introduced by the participants as an important part of the UK security agenda. During the discussion, the participants were divided into four groups facilitated by the authors, and were asked to complete three stages of analytical discussion: 1) To answer the question 'What has influenced security?'; 2) To describe the main dimensions of security; and 3) To reflect upon the authors' understanding of security based on the analysis of the policy documents. Focus group methodology facilitated access to how participants constructed and interpreted the role of climate change and securitisation via their own subjective and operational language 
and positioning. It also allowed the authors to capture a range of shared narratives, alongside features of organisational cultures, as participants built on the insights of peers from common communities of practice (Bryman, 2012).

\section{Data analysis}

An interpretive framework, allowing to "focus on meanings that shape actions and institutions, and the ways in which they do it" (Bevir and Rhodes, 2004, p.130), was used to analyse the meaning of policy - and how this meaning is implemented. Policy analysis contextualised the language and representations made in policy documents in the UK within expanded bodies of knowledge. Only the official government/parliament documents ${ }^{*}$ explicitly referring to 'climate change', climate-induced hazards and 'security' in the same context have been analysed for this paper. Over 400 results were identified, and 70 policy documents relevant to criteria above were analysed.

A more nuanced understanding of securitisation of climate change was achieved through the thematic analysis of transcripts of the focus group discussion. An inductive approach was taken, with initial higher level coding based on the key discussion themes such as drivers of security agenda and roles in security. Further lower level coding was developed and refined as data analysis progressed, including the analysis of specific events and examples of the actions taken. Thematic analysis was chosen due to the complexity of the dataset and the need for a flexible analytical process to provide structure to the findings (Howitt and Cramer, 2011) and allowed identification of a variety of approaches to securitisation.

\section{Exploring securitisation of climate change in the UK}

\section{Social practice: The context of climate change risks securitisation}

In order to understand the securitisation of climate change risks, it is important to assess the key elements and drivers shaping how this securitisation process developed in the UK. The lens of power - and the role of climate change in political agenda - helps understanding the shifts in how climate change risks are addressed and the associated distribution of governmental responsibility. Neoliberalism primarily sees climate change as an economic issue (Oels, 2006), and is thus considered through energy supply and demand, market efficiency etc. (Lovell et al., 2009). More recently however a new story line - securitisation has appeared, offering an actionable and 'practical' solution to a problem. In 2004, Sir David King (the then UK's government chief scientific adviser) stated that 'climate change in the most severe problem that we are facing today, more serious even that the threat of terrorism', as it affects millions of people globally. This was echoed by John Aston (2006) who emphasised that 'we need to treat climate change not as a long-term threat to our environment but as an immediate threat to our security and prosperity'. The UK government recognises that security and prosperity are closely entwined, and it is for this reason that the security implications of just climate change need to be taken seriously. For example, the greatest threat identified from the 2007 UK floods was the risk that the economic damage caused would impact upon the UK's economic status which, in turn, would undermine confidence in the UK government and create societal tensions (Pitt, 2008). The NRR 2017 states that the risk of high temperatures will have an impact on 'health, well-being and productivity' (Cabinet Office, 2017, p.8, emphasis added). Climate change has also been

\footnotetext{
${ }^{*}$ I.e. the documents available at the gov.uk and parliament.uk
} 
acknowledged by government departments, which traditionally would not have been concerned with such issues. For instance, the Ministry of Defense (MoD) has published (and later updated) a detailed Sustainable Development strategy, in which climate change is noted as playing an important role (MOD, 2011).

Closely related to the climate change agenda is the risk from natural hazards: projected changes in the climate include temperature increases on land and at sea, sea-level rise, melting of glaciers and ice caps, and changing and irregular rainfall patterns (IPCC, 2014). This points towards consideration, and potential conflation, of climate change as a security issue. The evidence and consequences of such risks are highlighted in the NRR: "As well as a trend towards warmer winters and hotter summers, sea levels around the UK's coast are rising by around $3 \mathrm{~mm}$ a year and there is evidence of changing rainfall patterns. Heavy rainfall and flooding, such as the UK saw over the winter of 2015/16, illustrate the costs and disruption that can be caused by extreme weather" (Cabinet Office, 2017, p.8).

\section{Discursive practice of climate change risks securitisation}

Discursive practice focuses on arguments that evidence securitisation of climate change risks in policies and government and parliament documents. In the UK policy climate change is presented from two perspectives: as a challenge that needs mitigating, and as a challenge that poses risks and therefore needs to be adapted to. When the UK Climate Change Programme was first initiated during 1994, its focus was largely on climate change mitigation, aiming to return carbon emissions to 1990 levels by 2000, and further reduce the emissions by $80 \%$ by 2010. It became apparent in 2006 that the 2010 target would not be met, and as a consequence the 2008 Climate Change Act changed the targets to $80 \%$ reduction by 2050 . CCA then started to receive more attention, leading to the creation of the Climate Change Risk Assessment, and establishment of the National Adaptation Programme. Of particular interest here is the way that climate change, and its associated strategies for adaptive amelioration, is approached in highly specific ways. Selective features of climate change - its 'actionable elements', manifestations that are visible and amenable to intervention rather than more ambiguous, long-term and unmanageable aspects - are foregrounded. The main focus of the National Adaptation Programme is on flooding (HMG, 2013), however the UK Climate Change Risk Assessment 2017 Evidence Report also adds high temperatures, water shortage, risks to ecosystems, food security, and pests and diseases as its top six areas of climate change risks. Other climate-related risks discussed in the report include exposure of interdependent infrastructure networks to multiple hazards; air quality; risks to culturally valued buildings; and international human displacement (CCC, 2016). Climate change itself does not feature in the national risk matrices as it is seen as a part of 'longer-term vulnerabilities or broader issues that have the potential to negatively impact on society, but which are not confined to single events' (Cabinet Office, 2015, p.27); however, the latest NRR points out that 'long-term trends (such as climate change) increase the chance or severity of civil emergencies' (Cabinet Office, 2017, p.69). Such practices further demonstrate the ways in which risks and responsibilities associated with climate change are subjected to politicised definitional processes. The UK Climate Change Risk Assessment explains why climate change is not seen as a risk: it is assessed differently because the climate change risk assessment focuses on long-term risks (up to the year 2100) that can aid long-term and short-term decisions on adaptation policy, whereas the National Risk Assessment focuses on most significant specific threats and hazards over a five year period, i.e. those that could threaten national security interests, and 
drives contingency planning for responding to and recovering from these threats and hazards (HMG, 2012).

Whilst the links between climate change and some natural hazards are obvious, they are only occasionally discussed together in policy documents (Table 1). This can be explained by the fact that natural hazards are often covered by the DRR and resilience agendas that tend to be over-influenced by reactive, emergency response/ preparedness practices; agendas that are responsibilities of different departments that do not sufficiently overlap with policies aimed at CCA (Chmutina et al., 2017). Such partial coherences, drawn towards the poles of emergency planning and security, further express the degrees of intersubjectivity that permeate the securitisation of climate change risks.

Notable here is how the securitisation of climate change is a recent development, and was not mentioned by the National Security Strategies until 2008. Climate change is often described to be a factor that will increase the intensity of the natural hazards in the future, $a$ 'risk multiplier': ' "Building resilience will therefore need to consider the impacts of climate change over the lifetime of the infrastructure and make allowances for the magnitude of future hazards in investment decisions to secure the necessary adaptation over time" (Cabinet Office, 2013, p.28). A number of political leaders and academics have stated that climate change is now becoming an issue of national security (Helm, 2014; Harris, 2012). However, the NSS (although explicitly mentioning climate change) does not describe it as a risk. Climate change is also prominently mentioned in the NSS Review (HMG, 2015) and is treated as a global issue, and natural hazards (including climate-induces) are the highest priority (Tier 1) risk, due to the high impact and disruption such events can cause (HMG, 2010).

Table 1 Content analysis of successive government responses to climate change 2000-2015 demonstrates that only few documents cover both natural hazards and climate change

\begin{tabular}{|c|c|c|}
\hline Year & Natural hazards & Climate change \\
\hline 2000 & & Climate Change Programme \\
\hline 2004 & Civil Contingencies Act & \\
\hline 2005 & \multicolumn{2}{|c|}{ Making space for water } \\
\hline 2006 & & Climate Change Programme (revised) \\
\hline 2008 & Planning Act & Climate Change Act \\
\hline 2009 & The Flood Risk Regulations & MOD Climate change strategy \\
\hline \multirow{2}{*}{2010} & Flood and Water Management Act & \\
\hline & $\begin{array}{l}\text { Strategic framework on improving the } \\
\text { resilience of critical infrastructure to } \\
\text { disruptions from natural hazards }\end{array}$ & \\
\hline 2011 & \multicolumn{2}{|c|}{ Natural Hazards and Infrastructure: Keeping the country running } \\
\hline
\end{tabular}

\footnotetext{
† This development could also be considered as a scalar multiplier however maintaining fidelity to governmental lexicon forms the basis of our analysis.
} 


\begin{tabular}{|l|l|l|}
\hline 2012 & & The UK climate change risk assessment \\
\hline 2013 & $\begin{array}{l}\text { National Risk Register of Civil } \\
\text { Emergencies }\end{array}$ & Adapting to Climate Change \\
\cline { 2 - 3 } & $\begin{array}{l}\text { Improving UK's ability to absorb, respond } \\
\text { to and recover from emergencies }\end{array}$ & \\
\cline { 2 - 3 } & $\begin{array}{l}\text { Reducing the threats of flooding and } \\
\text { coastal change }\end{array}$ & \\
\cline { 2 - 3 } 2014 & $\begin{array}{l}\text { The national adaptation programme: making the country resilient to a changing climate } \\
\text { The national flood emergency framework }\end{array}$ & \\
\hline 2015 & $\begin{array}{l}\text { National Risk Register of Civil } \\
\text { Emergencies }\end{array}$ & \multicolumn{2}{|c|}{ National Risk Register of Civil Emergencies ${ }^{\ddagger}$} \\
\hline 2017 & \multicolumn{2}{|c}{} \\
\hline
\end{tabular}

The Climate Change Risk Assessment states that it "has mainly examined the risks of a changing climate in the UK - not to the UK from abroad" (HMG, 2012, p.9). The 2011 Building Stability Overseas Strategy gives little attention to the mechanisms for dealing with the suggested security threat of climate change either (DFID, 2011). It is only the Foresight report 'International Dimensions of Climate Change' (2011) that explicitly discusses the implications of global climate change for the UK security, including more calls for international humanitarian assistance and contingency arrangements; UK domestic protests increase as a result of more severe and widespread impacts from climate change impacts overseas; future defense planning fails to incorporate the full impacts of climate change. This however has not been reflected in the national policy to date. Whilst climate change attracts securitised framings and responses, it is absent in official security doctrine. This makes its securitising features subtler.

Through the discursive practices the case is made for the securitisation of climate change. Although climate change is not treated as a risk itself, the severity of risks exacerbated by climate change dominates the political debates.

\section{Text: interrogating the securitisation of climate change risks}

The analysed texts demonstrated a number of 'influencers' that have effectively enabled the securitisation of climate change. Drawing upon the focus groups discussions it was possible to identify the most prominent themes with relation to climate change and security in the UK. The focus group participants produced a timeline (Figure 3) of the main events and background events that shaped the UK's security discourses since the 1990s. In total, the 23 delegates posted 116 separate 'influences's, each of which was deemed to have determined

\footnotetext{
${ }^{\ddagger}$ Here it is important to note the shift from natural hazards focus to a link between natural hazards and climate change, which can lead to an increase in severity of civil emergencies as already discussed in this section. $\S$ The focus group participants were not explicitly asked to focus on climate change or climate change-related events; instead they were asked to write down 'What has influenced security' and place it on a timeline.
} 
or shaped security discourses, with a particular focus upon 'influences' occurring during the last 10 years.

(re:

1990

2000

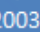

- Heatwave across Europe (incl.UK)

- Real Earth Summit

- Floods in the UK
- Thames barrier built

2006

2013

- Floods in the UK

2014

- Floods in the UK

Figure 3 Summary of selective 'security influencers' that are relevant to climate change discussion identified by the focus group participants

The participants acknowledged climate change as a prominent process, however it was noted that it was specific climate-induced events (i.e. floods and storms) that trigger a change in security policy - and not explicitly the long-term process of climate change. It was also felt that climate change could become even more prominent in security discourses due to the likely impacts on global and regional inequalities and any subsequent knock-on consequences (population migration, civil unrest resulting from crop failures).

The results of the focus group validated our findings: similarly to policy documents climaterelated events that have national - economic - impact are seen as a key driver of climate change securitisation. When discussing risks imposed by climate change, extreme weather events (non-specific) are seen as the largest risk posed by climate change to the UK security, mainly because such events can affect prosperity.

Based on the analysis of the focus groups and policy documents, it appears that securitisation of climate change risk is made up of three elements; they structure the dominant discourse around climate change in the UK policy and debate:

- Natural hazards (in particular flooding);

- Conflict over and supply of resources (energy, food and water);

- Economic damage.

These elements have an immediate impact on the UK and its society, thus on a national level such trend focuses on adaptation - i.e. preparedness to the impacts of climate-induced hazards; and whilst it is understood that a more prominent political action on a global level is required in order to mitigate the root causes (GHG emissions), such understanding does not form a part of the security agenda.

\section{What is being securitised?}


Fjader (2014) argues that 'security as a strategy aims to stop the threat before it materialises or escalates, or [...] to defeat it as soon as possible' (p.123). This is however clearly not the case with the securitisation of climate change. Whilst the risks posed by climate change are high on the political agenda, the climate change mitigation efforts (that would address the actual causes of the risk) are gradually being abandoned: under the general banner of austerity cuts to renewable energy subsidies or energy efficiency schemes have become common. The Department for Energy and Climate Change $\left(\right.$ DECC $\left.^{\star \star}\right)$ played a major role in addressing the mitigation of climate change; however it did so in silo. Furthermore, although the UK is still presenting itself as a leader in fighting climate change (as was emphasised during the COP21), the gap between the policy targets and the policy implementation is growing (Gillard, 2016). Thus, and despite rhetorical claims to the contrary, climate change at large has been gradually relegated from the government's agenda. The discourse will now inevitably shift towards the specific climate-induced hazards, which are having an immediate impact in the UK, rather than on the long-term overall effects of climate change, which are uncertain (Figure 4).

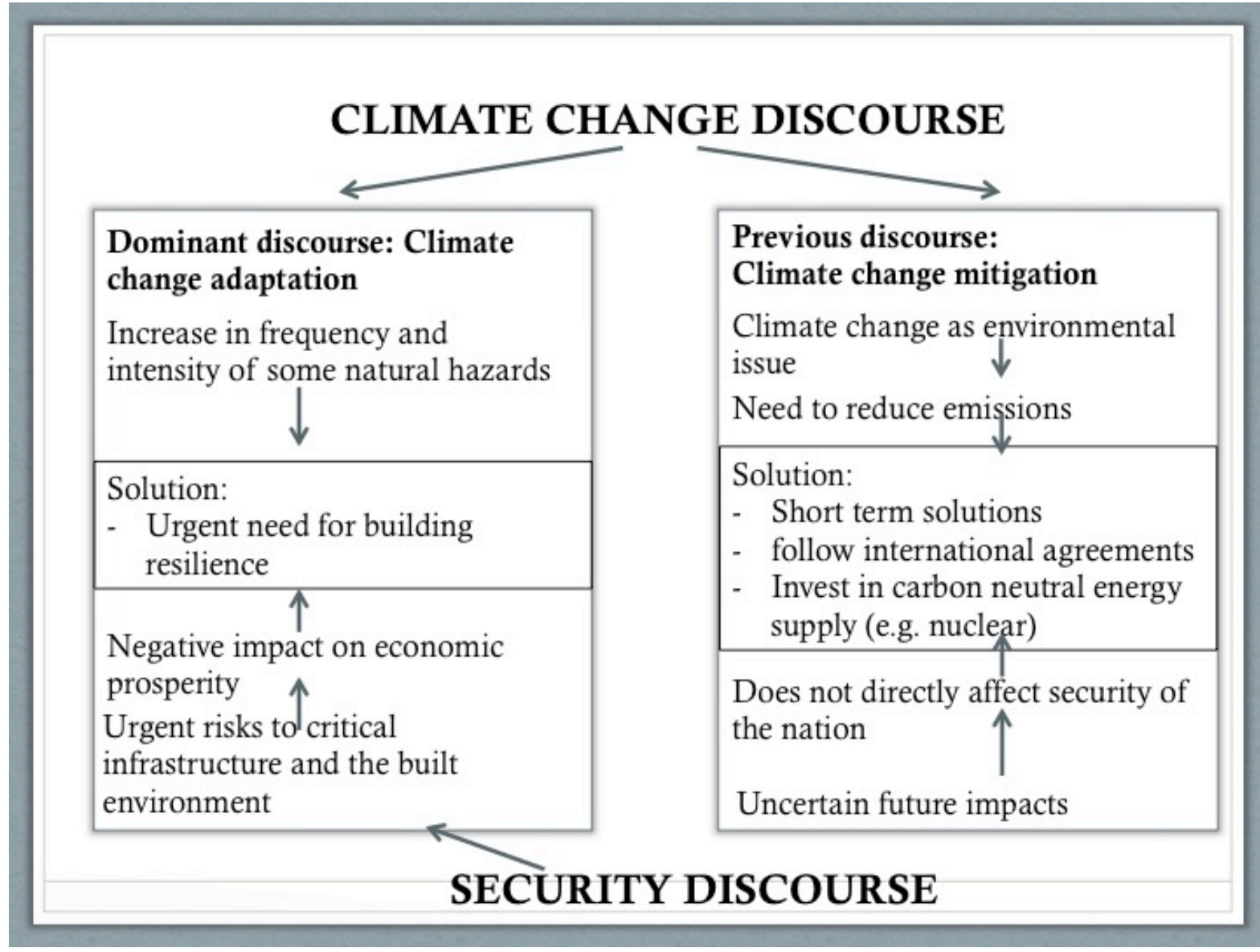

Figure 4 Simplified representation of variations to climate change discourses and the securitisation process

Securitisation of climate change has gradually been 'locked' into a particular path of development - risks of natural hazards; thus the actual cause of the problem anthropogenic GHG emissions - has been largely ignored in the security discourse and, similar to the framing of risks in terms of economic impacts outlined above, remains yoked to free market economic modes of production and neoliberal discourses more broadly. Most of

** DECC became part of the Department for Business, Energy and Industrial Strategy in July 2016. 
the climate change security strategies therefore focus on increasing the coping capacity of individuals and the nation rather than on long-term preventative strategies that can help climate change mitigation. Responses narrowly framed through the lens of securitisation attend most heavily to the consequences rather than the causes of climate change.

The UK is not prepared for the impacts of climate change: whilst its contributions to mitigation efforts are critical, the impacts of climate change can already been seen today, and therefore it is clear that there is a need for more substantive mitigation strategies (CCC, 2016). Such an approach leads to the following argument: climate change risks play out as both separate and intertwined agendas when human-induced activities can compound natural processes, and at the same time they are increasingly conflated within the policy discourse. This argument is not new: Beck (2008) argues that risks are increasingly becoming anthropogenic, with the boundaries between human-induced threats and natural hazards being eroded.

The erosion of such boundaries is evident from the UK policy. Climate change is seen through two lenses simultaneously: as a security risk, and as a risk to security. The former means that climate change and its impacts will have an effect on wellbeing and prosperity; the latter focuses on the disruptive impacts of climate change (e.g. flooded electricity stations). The UK policy and discussions around climate change security mainly focus on the prosperity of the UK (i.e. securitisation takes place in order to protect economic development and economic prosperity of the country). Climate change is securitised because of the economic implications of its impacts and the uncertainties that come with climate change.

The risk to security is thus seen through a prism of a specific hazard, which creates issues as climate change increases the frequency and intensity of a hazard. There is also a temporality issue: climate change is perceived as a distant problem with uncertain (but potentially catastrophic) impacts. Therefore the short-term horizon of a specific hazard is much easier to deal with after a disastrous event. Whilst the long-term thinking is critical for the risks associated with climate change, singling out a more specific risk with a more prominent impact (e.g. flooding) makes the task seem manageable.

Episodic perturbations, such as seasonal flooding, bring dynamic temporalities, shifting governmental relations and additional security framings to the process. This in turn reveals a paradoxical process at the heart of state's approaches to climate change, and highlights an additionally nuanced and complex articulation of neoliberalism (Chmutina et al., 2016). On the one hand, and principally during the time ahead of shock, responses to climate change have mobilised a centrifugal direction of governance, making non-state actors, localities and individuals responsible for their own vulnerabilities. Yet once large-scale climate-induced events occur, the state exercises its dominance via its co-ordination of command, control and response alongside deployments of military hardwares and other state assets. Such centripetal post-event practices also serve to bring the security-focused response to climate change into sharp relief.

\section{Conclusions}

There is evidence to suggest that climate change has been 'securitised', in a sense that there has been a (re)framing of climate change from an environmental/developmental perspective to a security perspective. However, a subsequent change in practice, programming and funding has not yet occurred. The inclusion of climate change and natural hazards into the NSS is a recent development and outlines a range of climate security- 
related 'threats' (Harris, 2012). But the increase in climate risks is not natural by origin; instead it is a result of the increased vulnerabilities of a changing society, due to complex processes including urbanisation, economic development and globalisation (Bosher and Chmutina, 2017). However shifting governmental relations and ownership of risk identified above generates ambiguity over where the sites of responsibility for mitigating and adapting to climate change lie.

Since climate change has been securitised and closely tied with natural hazards, there should be more encouragement for the incorporation of CCA and DRR. Currently, whilst included in the security agenda, these two areas are perceived as separate, thus neglecting and underestimating their commonalities and goals, or being unable to overcome political constrains (Chmutina et al., 2017). Furthermore, decisions over significant investment in infrastructure may provide protection in the 'here and now' at enormous costs for future generations

Climate change risks are uncertain and cannot be fully eradicated; instead they can only be managed. Climate change has become an item in the security agenda, under which a number of other issues are discussed, in particular natural hazards, and food and energy supply; it will thus remain present in the political discourse. However, its current prominence may diminish over time - as it is currently happening with climate change mitigation depending on political attitudes to climate change of the leading party. The government mentality therefore needs to be changed and to become more holistic and long-term in order to address the temporality and uncertainly of such risks. Mobilising one-off actions will not defeat the risk of climate change and other risks related to it. It is important to recognise that the long-term risks of climate change that the UK (and most other nations) is currently facing might be a question of survival for other nations.

\section{References}

Abbott, C., Rogers, P. and Sloboda, J. (2007), Beyond terror: the truth about the real threats to our world, Rider, UK.

Aston, J. (2006), "World most wanted: climate change", BBC News, 8 Sept. 2006, available at: news.bbc.co.uk/2/hi/science/nature/5323512.stm (accessed 20 April 2018)

Balzacq, T. (2005), "The Three Faces of Securitization: Political Agency, Audience and Context”, European Journal of International Relations, Vol.11 No.2, pp.171-201.

Barnett, J. (2003), "Security and climate change", Global Environmental Change, Vol.13 No.1, pp.7-17.

Beck, U. (2008), "Risk Society's 'Cosmopolitan Moment”, Lecture at Harvard University November $12^{\text {th }}$. Available at: http://www.labjor.unicamp.br/comciencia/files/risco/ARUlrichBeck-Harvard.pdf (accessed 20 April 2018).

Beckett, M. (2007), "The case for climate security", The RUSI journal, Vol.152 No.3, pp.5459.

Bevir, M. and Rhodes, R. A. W., 2004, "Interpreting British governance", British Journal of Politics and International Relations, Vol. 6, pp.130-136.

Boas, I. (2015), Climate migration and security. Securitisation as a strategy in climate change politics, Routledge, NY. 
Boas, I. and Rothe, D. (2016), "From conflict to resilience? Explaining recent changes in climate security discourse and practice", Environmental politics, Vol.25 No.4, pp.613-632.

Bosher L.S. and Chmutina K. (2017), Disaster Risk Reduction for the Built Environment: An introduction, Wiley, London.

Brito, R.R. (2009), "Securitising climate change", paper presented at the IPSA World Congress of Political Science, 12-16 July, Santiago de Chile.

Bryman, A. (2012), Social Research Methods 4th ed, Open University Press, Oxford

Buzan B. (1991), People, States and Fear: An Agenda for International Security Studies in the Post Cold War Era, 2nd ed, Lynne Rienner, Boulder, CO

Buzan B,. de Wilde, J., and Wæver, O. (1998), Security: A New Framework for Analysis, Lynne Rienner, Boulder, CO

Buzan, B. and Weaver, O. (2003), Regions and Power, Cambridge University Press, Cambridge

Cabinet Office (2015), "National Risk Register of Civil Emergencies", available at: https://www.gov.uk/government/uploads/system/uploads/attachment data/file/419549/20150 331 2015-NRR-WA Final.pdf (accessed 20 April 2018).

Cabinet Office (2017), "National Risk Register of Civil Emergencies", available at: https://www.gov.uk/government/uploads/system/uploads/attachment data/file/644968/UK N ational Risk Register 2017.pdf (accessed 20 April 2017).

Chmutina, K., Bosher, L., Dainty, A. et al. (2015), « D7.1 Report on regional workshop, EvoCS Project deliverable", available at: http://evocs-project.eu/deliverables (accessed 20 April 2018)

Chmutina, K., Jigyasu, R., and Bosher, L. (2017), "Integrating DRR including CCA into the delivery and management of the built environment", Kelman, I., Mercer, J. \& Gaillard, J.C (ed.), Routledge Disaster Risk Reduction and Climate Change Adaptation Handbook, Routledge, UK, pp.264-274.

Chmutina, K., Lizarralde, G., Dainty, A. and Bosher, L. (2016), "Unpacking resilience security discourse", Cities, Vol. 58, pp. 70-79.

Coaffee, J. and Fussey, P. (2015), "Constructing Resilience Through Security and Surveillance: The Practices and Tensions of Security-driven Resilience", Security Dialogue, Vol.46 No. 1, pp. 86-105.

Committee on Climate Change (2016), "UK Climate Change Risk Assessment 2017. Synthesis report: priorities for the next five years", available at: https://www.theccc.org.uk/wp-content/uploads/2016/07/UK-CCRA-2017-Synthesis-ReportCommittee-on-Climate-Change.pdf (accessed on 20 April 2018).

Corry, O. (2012), "Securitisation and 'Riskization': Second-order security and the politics of climate change", Millenium, Vol.40 No.2, pp. 235-258.

Davoudi, S. (2014), "Climate Change, Securitisation of Nature, and Resilient Urbanism", Environment and Planning C: Politics and Space, Vol.32 No.2, pp. 360-75. 
De Wilde, J.H. (2008), "Environmental security deconstructed", Brauch, H. G. et al. (eds). Globalisation and the environmental challenges: Reconceptualizing Security in the 21st Century, Springer, Berlin, pp. 595-206.

DFID (2011), "Building stability overseas strategy", Stationary Office, UK.

Fairclough, N. (1992), Discourse and social change, Polity, Cambrindge.

Fjader, C. (2014), "The nation-state, national security and resilience in the age of globalization", Resilience, Vol.2 No.2, pp.114-129.

Floyd, R. (2008), "The environmental security debate and its significance for climate change", The international spectator, Vol.43 No.3, pp. 51-65.

Foresight (2011), "International Dimensions of Climate Change", Final Project Report, The Government Office for Science, London.

Fussey, P. and South, N. (2012), "Heading toward a new criminogenic climate: climate change, political economy and environmental security", White, R (ed.) Climate Change, Crime and Criminology, Springer, NY, pp.27-40

Gillard, R. (2016), “Unravelling the United Kingdom's climate policy consensus: The power of ideas, discourse and institutions", Global Environmental Change, Vol. 40, pp.26-36.

Harris, K. (2012), "Climate change in UK security policy: implications for development assistance?" ODI Working paper 342, available at:

http://www.odi.org/sites/odi.org.uk/files/odi-assets/publications-opinion-files/7554.pdf (accessed 20 April 2018)

Helm, T. (2014), "Ed Miliband: 'Britain is sleepwalking to a climate crisis'”, The Guardian, 15 Feb. 2014, available at https://www.theguardian.com/politics/2014/feb/15/uk-floods-climatechange-disaster-ed-miliband (accessed 20 April 2018)

Hollander, J. (2017), We looked at 1,154 climate science results and found no evidence of 'publication bias', The Conversation, 5 Oct. 2017, available at

https://theconversation.com/we-looked-at-1-154-climate-science-results-and-found-no-

evidence-of-publication-bias-84500 (accessed 25 May 2018)

HM Government (2010), "A strong Britain in an age of uncertainly: The national security strategy", Stationery Office, London

HM Government (2012), "UK Climate Change Risk Assessment: Government Report", Stationery Office, London

HM Government (2013), "The National Adaptation Programme Making the country resilient to a changing climate", Stationery Office, London

HM Government (2015), "National Security Strategy and Strategic Defense and Security Review 2015", Stationery Office, London

Howitt, D. and Cramer, D. (2011), Introduction to Research Methods. Prentice Hall, UK.

Huysmans, J. (1998). Security! What Do You Mean? From Concept to Thick Signifier, European Journal of International Relations, 4(2): 226-255.

IPCC (2014), "Summary for policymakers", Field, C.B., V.R. Barros, D.J. Dokken, et al. (eds.), Climate Change 2014: Impacts, Adaptation, and Vulnerability. Part A: Global and 
Sectoral Aspects. Contribution of Working Group II to the Fifth Assessment Report of the Intergovernmental Panel on Climate Change, Cambridge University Press, UK, pp.1-32.

Lovell, H., Bulkeley, H. and Owens, S. (2009), "Converging agendas? Energy and climate politics in the in UK", Environment and Planning C: Government and Policy, Vol. 27, pp.90109.

Kelman, I., Mercer, J. and Gaillard, J.C. (2017), The Routledge Handbook of Disaster Risk Reduction Including Climate Change Adaptation. Routledge,UK.

King, D. (2004), "Climate change science: Adapt, mitigate or ignore?", Science, Vol. 303, pp.176-177.

Monbiot, G. (2013), "Climate change? Try catastrophic climate breakdown", The Guardian, 27 September 2013, available at:

https://www.theguardian.com/environment/georgemonbiot/2013/sep/27/ipcc-climate-changereport-global-warming (accessed 20 April 2018).

McDonald, M. (2013), "Discourses of climate security", Political geography, Vol. 33, pp. 4251.

Mercer, J. (2010), "Disaster risk reduction of climate change adaptation: are we reinventing the wheel?", Journal of International Development, Vol. 22, pp. 247-264.

Ministry of Defense (2011), "MOD sustainable development strategy and delivery plan 2011 -2030", available at: https://www.gov.uk/government/publications/sustainable-developmentstrategy (accessed 20 April 2018).

Oels, A. (2006), "Rendering climate change governable: from biopower to advanced liberal government?", Journal of Environmental Policy and Planning, Vol.7 No.3, pp.185-207.

Pitt, M. (2008), "The Pitt Review: Learning Lessons from the 2007 floods", Cabinet Office. London.

Rasmussen, M.V. (2010), "Risk and Security", The International Studies Encyclopedia, Blackwell Publishing Lmt., UK.

Rogers-Hayden, T., Hatton, F.and Lorenzoni, I. (2011), “'Energy security' and 'climate change': Constructing UK energy discursive realities", Global Environmental Change, Vol. 21, pp. 134-142.

Schafer, M.S., Scheffran, J., \&Penniket, L. (2016), "Securitisation of media reporting on climate change? A cross-national analysis in nice countries", Security dialogues, Vol.47 No. 1, pp. 76-96.

Scott, S.V. (2012), "The securitisation of climate change in world politics: How close have we come and would full securitisation enhance the efficacy of global climate change policy?", Review of European Community and International Environmental Law, Vol. 21 No. 3, pp. 220-230.

Shin, H. and Choi, B.D. (2015), "Risk perception in UK climate chance and energy policy narratives", Journal of Environmental Policy and Planning, Vol. 17 No. 1, pp. 84-107.

UK mission to the UN (2007), "Energy, security and climate", Security Council Open debate UK concept paper, available at:

https://unfccc.int/files/application/pdf/ukpaper securitycouncil.pdf (accessed 20 April 2018). 
Von Lucke, F., Wellmann, Z. and Diez, T. (2014), „What's at stake in securitising climate change? Towards a differentiated approach", Geopolitics, Vol.19, 857-884.

Appendix 1: Full list of the analysed documents

\begin{tabular}{|c|c|c|c|}
\hline $\begin{array}{l}\text { Government } \\
\text { Department }\end{array}$ & Type & Year & Title \\
\hline $\begin{array}{l}\text { Cabinet } \\
\text { Office }\end{array}$ & Policy & $\begin{array}{l}2012 \\
2015 \\
2017\end{array}$ & National Risk Register of Civil Contingencies \\
\hline $\begin{array}{l}\text { Cabinet } \\
\text { Office }\end{array}$ & Guide & 2013 & $\begin{array}{l}\text { Improving UK's ability to absorb, respond to and } \\
\text { recover from emergencies }\end{array}$ \\
\hline $\begin{array}{l}\text { Cabinet } \\
\text { Office }\end{array}$ & Guide & 2011 & $\begin{array}{l}\text { Natural Hazards and Infrastructure: Keeping the } \\
\text { country running }\end{array}$ \\
\hline $\begin{array}{l}\text { Cabinet } \\
\text { Office }\end{array}$ & Statement & 2010 & $\begin{array}{l}\text { Strategic framework on improving the resilience } \\
\text { of critical infrastructure to disruptions from } \\
\text { natural hazards }\end{array}$ \\
\hline $\begin{array}{l}\text { Cabinet } \\
\text { Office }\end{array}$ & Act & 2004 & Civil Contingencies Act \\
\hline DECC & Policy & 2016 & DECC departmental plan 2015-2020 \\
\hline DECC & $\begin{array}{l}\text { Statement to } \\
\text { Parliament }\end{array}$ & 2015 & $\begin{array}{l}\text { Priorities for UK energy and climate change } \\
\text { policy }\end{array}$ \\
\hline DECC & Speech & 2015 & Secretary of State speech on Climate Change \\
\hline DECC & Speech & 2014 & Address to the Green Growth Summit \\
\hline DECC & Policy paper & 2014 & Annual energy statement \\
\hline DECC & Policy paper & 2014 & Community energy strategy \\
\hline DECC & Speech & 2014 & $\begin{array}{l}\text { Green social change: building an Energy Saving } \\
\text { Society }\end{array}$ \\
\hline DECC & $\begin{array}{l}\text { Statement to } \\
\text { Parliament }\end{array}$ & 2014 & Informal Energy and Environment Council \\
\hline DECC & Policy paper & 2014 & $\begin{array}{l}\text { Memorandum to the Energy and Climate Change } \\
\text { Committee: Post Legislative Scrutiny of the } \\
\text { Energy Act } 2008\end{array}$ \\
\hline DECC & Policy paper & 2014 & $\begin{array}{l}\text { Paris 2015: Securing our prosperity through a } \\
\text { global climate change agreement }\end{array}$ \\
\hline DECC & Speech & 2014 & $\begin{array}{l}\text { Publication of Paris 2015: Securing our } \\
\text { prosperity through a Global Climate Change } \\
\text { Agreement }\end{array}$ \\
\hline DECC & Policy paper & 2013 & $\begin{array}{l}2010 \text { to } 2015 \text { government policy: UK energy } \\
\text { security }\end{array}$ \\
\hline DECC & Policy paper & 2013 & Annual energy statement \\
\hline
\end{tabular}




\begin{tabular}{|c|c|c|c|}
\hline DECC & Policy paper & 2013 & $\begin{array}{l}\text { Going for Green Growth: The case for ambitious } \\
\text { and immediate EU low carbon action }\end{array}$ \\
\hline DECC & Policy & 2013 & $\begin{array}{l}\text { Preparing for and responding to energy } \\
\text { emergencies }\end{array}$ \\
\hline DECC & Speech & 2013 & Securing Britain's Energy Future \\
\hline DECC & Speech & 2013 & The energy security challenge \\
\hline DECC & Policy paper & 2012 & Annual energy statement \\
\hline DECC & Speech & 2012 & $\begin{array}{l}\text { Climate \& Resource Security Dialogue for the } \\
21^{\text {st }} \text { Century conference }\end{array}$ \\
\hline DECC & Speech & 2012 & $\begin{array}{l}\text { Edward Davey speech to Climate \& Resource } \\
\text { Security Dialogue for the } 21^{\text {st }} \text { Century } \\
\text { conference }\end{array}$ \\
\hline DECC & Policy paper & 2012 & Electricity market reform: policy overview \\
\hline DECC & Policy paper & 2012 & $\begin{array}{l}\text { Government Response to the House of } \\
\text { Commons Energy and Climate Change Select } \\
\text { Committee Report into the draft Energy Bill }\end{array}$ \\
\hline DECC & Speech & 2011 & Climate Impacts Study \\
\hline DECC & Enquiry & 2010 & Electricity market report \\
\hline DECC & Speech & 2010 & Sustainable energy security \\
\hline DECC & Webpage & & About us \\
\hline DECC & Policy page & & Climate change and energy security \\
\hline DEFRA & Report & $\begin{array}{l}2012 \\
2017\end{array}$ & The climate change risk assessment \\
\hline DEFRA & Policy & $\begin{array}{l}2000 \\
2006\end{array}$ & Climate change programme \\
\hline DEFRA & Policy & 2013 & $\begin{array}{l}\text { Reducing the threats of flooding and coastal } \\
\text { change }\end{array}$ \\
\hline DEFRA & Framework & 2013 & $\begin{array}{l}\text { The national flood emergency framework for } \\
\text { England }\end{array}$ \\
\hline DEFRA & Report & 2012 & Adapting to climate change \\
\hline DEFRA & Strategy & 2005 & Making space for water \\
\hline DEFRA & Policy paper & 2015 & $\begin{array}{l}2010 \text { to } 2015 \text { government policy: climate change } \\
\text { international action }\end{array}$ \\
\hline DFID & Report & 2011 & $\begin{array}{l}\text { Achieving food security in the face of climate } \\
\text { change }\end{array}$ \\
\hline DFID & $\begin{array}{l}\text { Impact } \\
\text { assessment }\end{array}$ & 2015 & Global Agriculture and Food Security Program \\
\hline DFID & Speech & 2014 & $\begin{array}{l}\text { Forests and climate change in the post- } 2015 \\
\text { agenda }\end{array}$ \\
\hline DFID & Speech & 2014 & $\begin{array}{l}\text { Taking action in response to the IPCC report on } \\
\text { climate impacts, adaptation and vulnerability }\end{array}$ \\
\hline DFID & Policy paper & 2013 & $\begin{array}{l}2010 \text { to } 2015 \text { government policy: climate change } \\
\text { impact in developing countries }\end{array}$ \\
\hline DFID & Speech & 2012 & Coping with climate change and natural disasters \\
\hline DFID & Speech & 2012 & $\begin{array}{l}\text { Forests - tackling illegal logging and climate } \\
\text { change }\end{array}$ \\
\hline DFID & Policy paper & 2011 & Building stability overseas strategy \\
\hline DFID & Speech & 2010 & Climate Change \\
\hline FCO & Speech & 2015 & Foreign Secretary's Clean Energy Future speech \\
\hline $\mathrm{FCO}$ & Speech & 2014 & $\begin{array}{l}\text { Climate Change: Politics, Economics and } \\
\text { Partnerships }\end{array}$ \\
\hline FCO & Speech & 2014 & Foreign Secretary speech on climate change \\
\hline
\end{tabular}




\begin{tabular}{|c|c|c|c|}
\hline FCO & Speech & 2011 & $\begin{array}{l}\text { Climate change: "our values, security and } \\
\text { prosperity compel us to act" }\end{array}$ \\
\hline FCO & Policy page & & Climate change impact in developing countries \\
\hline FCO & Speech & 2010 & $\begin{array}{l}\text { An effective response to climate change } \\
\text { "underpins our security and prosperity" }\end{array}$ \\
\hline $\begin{array}{l}\text { HM } \\
\text { Government }\end{array}$ & Policy review & 2015 & $\begin{array}{l}\text { National Security Strategy and Strategic Defense } \\
\text { and Security Review } 2015\end{array}$ \\
\hline $\begin{array}{l}\text { HM } \\
\text { Government }\end{array}$ & Policy & 2013 & $\begin{array}{l}\text { The National Adaptation Programme Making the } \\
\text { country resilient to a changing climate }\end{array}$ \\
\hline $\begin{array}{l}\text { HM } \\
\text { Government }\end{array}$ & Report & 2012 & $\begin{array}{l}\text { UK Climate Change Risk Assessment: } \\
\text { Government Report }\end{array}$ \\
\hline $\begin{array}{l}\text { HM } \\
\text { Government }\end{array}$ & Policy & 2010 & $\begin{array}{l}\text { A strong Britain in an age of uncertainly: The } \\
\text { national security strategy }\end{array}$ \\
\hline $\begin{array}{l}\text { HM } \\
\text { Government }\end{array}$ & Act & 2010 & Flood and water management act \\
\hline $\begin{array}{l}\text { HM } \\
\text { Government }\end{array}$ & Regulation & 2009 & Flood Risk Regulation \\
\hline $\begin{array}{l}\text { HM } \\
\text { Government }\end{array}$ & Act & 2008 & Planning Act \\
\hline $\begin{array}{l}\text { HM } \\
\text { Government }\end{array}$ & Act & 2008 & Climate Change Act \\
\hline $\begin{array}{l}\text { House of } \\
\text { Lords }\end{array}$ & Written evidence & 2013 & Soft power and UK influence \\
\hline Met Office & Webpage & 2016 & Climate security \\
\hline Met Office & Report & 2015 & Food insecurity and climate change \\
\hline Met Office & Review & 2012 & Climate impacts on food security and nutrition \\
\hline MoD & Strategy & 2011 & $\begin{array}{l}\text { MOD sustainable development strategy and } \\
\text { delivery plan } 2011-2030\end{array}$ \\
\hline MoD & Strategy & 2009 & Climate Change Strategy \\
\hline PM Office & Speech & 2014 & $\begin{array}{l}\text { UN Climate Summit 2014: David Cameron's } \\
\text { remarks }\end{array}$ \\
\hline $\begin{array}{l}\text { The Scottish } \\
\text { Government }\end{array}$ & Policy & 2014 & $\begin{array}{l}\text { Climate Ready Scotland: Scottish Climate } \\
\text { Change Adaptation Programme }\end{array}$ \\
\hline
\end{tabular}


Appendix 2: Anonymised list of focus group participants

\begin{tabular}{|c|c|}
\hline Organisation description & Role description \\
\hline Academia & Professor in social science \\
\hline Private & Chief risk assessment consultant \\
\hline Think tank & Chief policy analyst (security) \\
\hline Government & Senior policy advisor (foreign affairs) \\
\hline Think tank & Activist \\
\hline Private & Risk assessment consultant \\
\hline Think tank & Senior researcher (strategy) \\
\hline NGO & Project coordinator \\
\hline Think tank & Senior policy analyst \\
\hline Police & Counter-terrorism advisor \\
\hline Government & Senior policy advisor (defence) \\
\hline Academia & Profession in security \\
\hline Government & Senior policy advisor (security and justice) \\
\hline Government & Senior policy advisor (security and justice) \\
\hline NGO & Disaster management expert \\
\hline Academia & Professor of Peace studies \\
\hline Private & Senior risk assessment consultant \\
\hline Think tank & Senior policy analyst (sustainability) \\
\hline Government & Senior policy advisor (defence) \\
\hline Government & Senior policy advisor (knowledge and innovation) \\
\hline Government & Senior policy advisor (emergency response) \\
\hline Academia & Senior researcher in defence \\
\hline Academia & Senior researcher (peace studies) \\
\hline
\end{tabular}

